\title{
A RPMGF em 2019 e a estratégia da sua indexação internacional
}

Alberto Pinto Hespanhol*

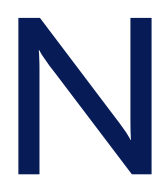

o último ano foi atingida uma boa parte dos objetivos anteriormente traçados para o Novo modelo editorial da Revista, ${ }^{1-2}$ à custa do desenvolvimento do Corpo Editorial e da otimização do processo/fluxo editorial. A atividade global dos Editores e a consolidação de uma vasta equipa de Revisores permitiram que fossem alcançados esses bons resultados.

É justo agradecer à Equipa Coordenadora (Diretor da revista e Editores Adjuntos) a dinamização que no último ano fizeram na Revista, com a contribuição relevante dos Editores e dos Revisores, aos quais agradecemos a competência, a disponibilidade e o rigor científico demonstrados no processo editorial. É de salientar a colaboração dos Editores no processo de tutoria dos editores juniores e manifestar o nosso profundo agradecimento aos Revisores que durante o ano de 2019 cooperaram com a RPMGF.

Na reunião anual de editores, em 23 de novembro de 2019, na Póvoa do Varzim, foi discutida a estratégia de indexação internacional da revista, à luz do resultado das avaliações da SCOPUS de 2019 e da MEDLINE de 2015. Neste âmbito, e como forma de melhorar a qualidade técnica de alguns artigos, decidiu-se trabalhar na

*Editor Chefe da Revista Portuguesa de Medicina Geral e familiar promoção de revisões sistemáticas em detrimento das revisões baseadas na evidência (RBE) ${ }^{3}$

Assim, no futuro, serão rejeitadas todas as novas submissões de RBE, passando apenas a aceitar revisões sistemáticas ou revisões clássicas de elevada pertinência, utilidade ou originalidade.

Finalmente, não é demais voltar a expressar um muito obrigado pela colaboração, dedicação e empenho prestados à RPMGF pela Equipa Coordenadora, Conselho Editorial, Revisores, Conselho Científico e todos os profissionais incluídos na ficha técnica da Revista.

\section{REFERÊNCIAS BIBLIOGRÁFICAS}

1. Nogueira R.A partilha do conhecimento num novo ciclo [Sharing knowledge in a new cycle]. Rev Port Med Geral Fam. 2017;33(3):170. Portuguese

2. Hespanhol AP. Contributo de novo modelo editorial da revista para a formação e a investigação em medicina geral e familiar [Contribution of a new editorial model for contiuous education and research in general and family medicine]. Rev Por Med Geral Fam. 2017;33(4):242. Portuguese

3. Rodrigues D, Dias CV, Heleno B. Como responder a dúvidas clínicas [How to answer to a clinical question]. Rev Port Med Geral Fam. 2019;35(2): 155-66. Portuguese

\section{ENDEREÇO PARA CORRESPONDÊNCIA}

E-mail: hespanhol@netcabo.pt

https://orcid.org/0000-0002-1212-4487 